Saudi Journal of Oral and Dental Research

Abbreviated Key Title: Saudi J Oral Dent Res

ISSN 2518-1300 (Print) |ISSN 2518-1297 (Online)

Scholars Middle East Publishers, Dubai, United Arab Emirates

Journal homepage: https://saudijournals.com

Case Report

\title{
Chondroid Syringoma, an Unknown Tumor: About A Case
}

H. Kabbaj ${ }^{1 *}$, M-L. E. Ngoua ${ }^{1}$, Z. Benzenzoum ${ }^{1}$, Z. Aziz ${ }^{1}$, N. Mansouri-Hattab ${ }^{1}$

${ }^{1}$ Maxillofacial, Aesthetic and Stomatology Surgery Department, Ibn Tofail hospital, UHC Moammed VI, Marrakech, Morocco

DOI: $10.36348 /$ sjodr.2021.v06i04.006

| Received: 18.03.2021 | Accepted: 26.04.2021 | Published: 30.04.2021

*Corresponding author: H. Kabbaj

\section{Abstract}

Chondroidsyringoma is a rare benign skin tumor whose preferential location remains the craniofacial region. It is characterized by a double component; epithelial and mesenchymal. We report the case of a 72-year-old female patient with a polypoid-like tumor located in the middle thirds of the free edge of the right nostril wing. After surgical excision, the histology is in favor of a chondroidsyringoma. No recurrence was noted after a follow-up of 20 months.

Keywords: Chondroidsyringoma, adnexal skin tumor, treatment.

Copyright () 2021 The Author(s): This is an open-access article distributed under the terms of the Creative Commons Attribution 4.0 International License (CC BY-NC 4.0) which permits unrestricted use, distribution, and reproduction in any medium for non-commercial use provided the original author and source are credited.

\section{INTRODUCTION}

Chondroidsyringoma is a rare skin tumor, belonging to the group of adnexal skin tumors. This is a benign tumor with a good prognosis, the management of which is based on complete excision of the tumor lesion. Little known to surgeons and pathologists, it is part of the differential diagnosis of many skin tumors of the face including both benign and malignant tumors. We report a case of slow growing nasal chondroidsyringoma with mild nasal obstruction ipsilateral to the tumor taken after surgical resection.

\section{PATIENT AND OBSERVATION}

A 72-year-old woman with no particular pathological history presented with a lump in the right nostril wing that had progressed for a year. Clinical examination revealed the presence of a polypoid mass based on a sessile implantation, painless, non-ulcerated, with a smooth and regular surface, non-telangiectatic, $12 \mathrm{~mm}$ in diameter, which sits at the level of the middle $2 / 3$ of the border. Close up to the wing of the right nose without filling the nasal vestibule (Figures 1 and 2). General examination was normal with no palpable cervical lymphadenopathy. An excisional biopsy of the lesion was performed under local anesthesia with a lateral margin of $3 \mathrm{~mm}$ and removing $2 \mathrm{~mm}$ of alar cartilage in depth. The loss of substance was closed by direct suture without deformation of the wing of the nose or impact on the respiratory function (Figures 3, 4, 5, 6 and 7). Histology revealed a benign adnexal tumor with a double epithelial and mesenchymal component with a positive immunostaining of myoepithelial cells to the S100 protein, making the diagnosis of chondroidsyringoma. No recurrence was noted after a 20-month follow-up, nor any impact on nasal morphology or respiratory function.

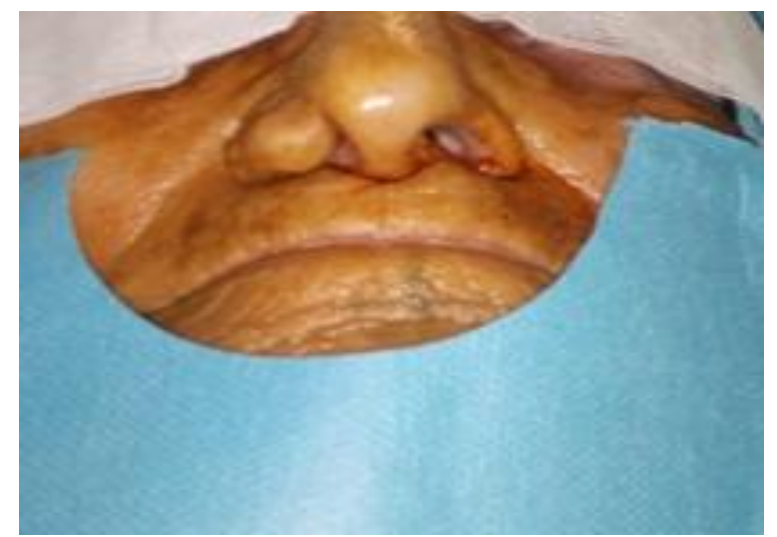

Fig-1: Polypoid tumor of the middle two-third of the free adge of the right ala of the nose with obstucting the nostril (Basal view)

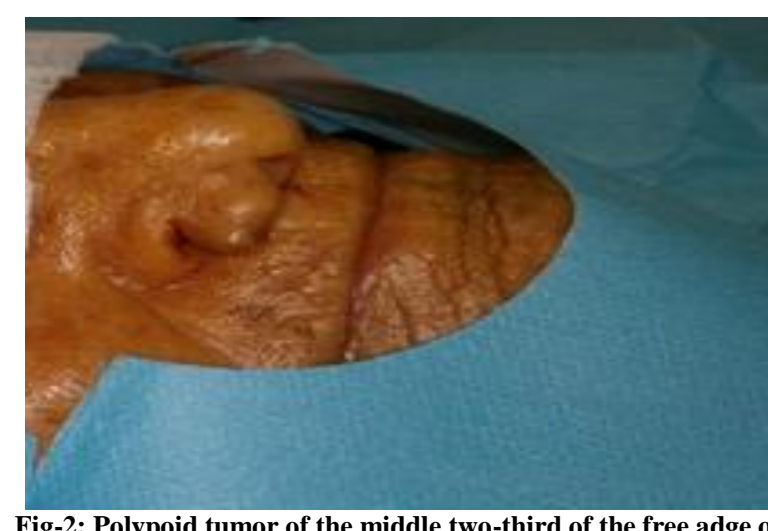

Fig-2: Polypoid tumor of the middle two-third of the free adge of the right ala of the nose with obstucting the nostril (Profile view) 


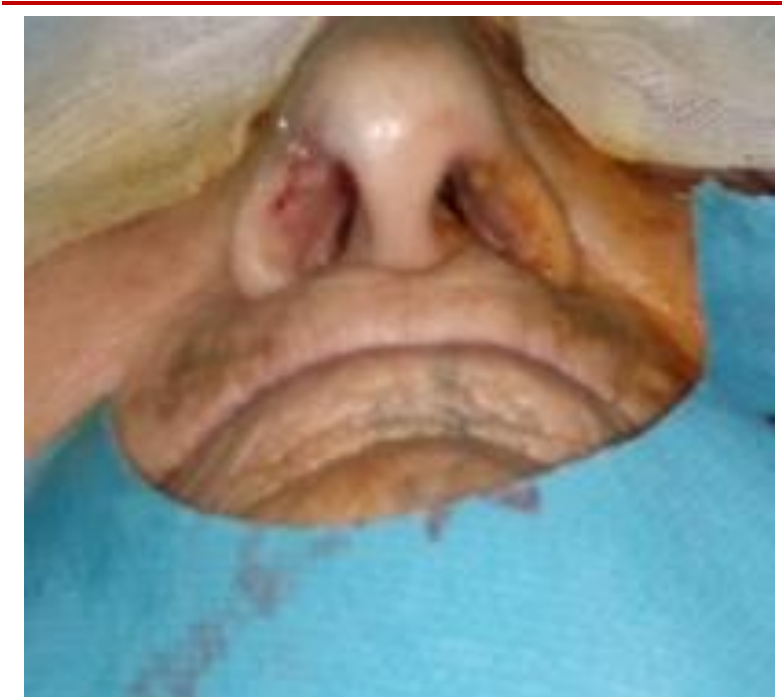

Fig-3: Excisional biopsy with 3mm margins. Direct suture closure (Basal view)

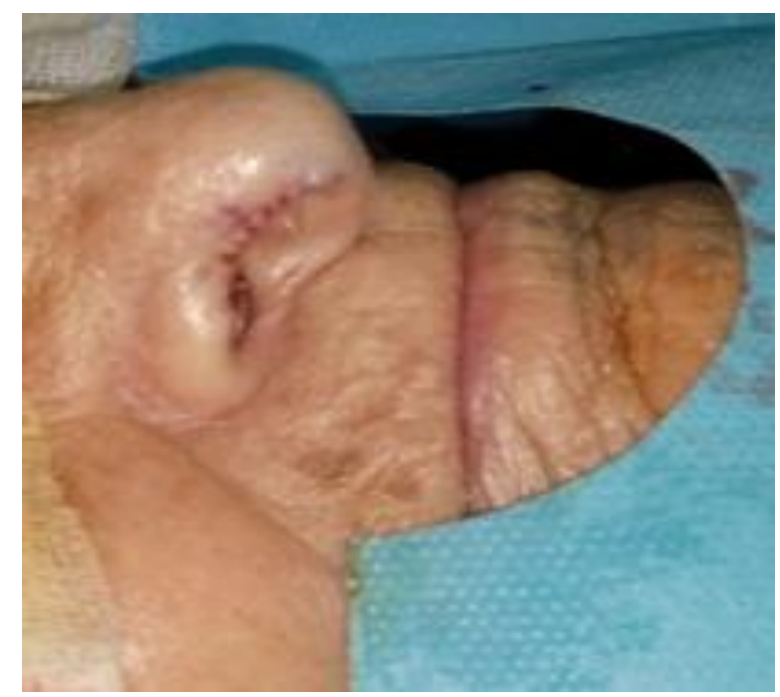

Fig-4: Excisional biopsy with 3mm margins. Direct suture closure (Profile view)

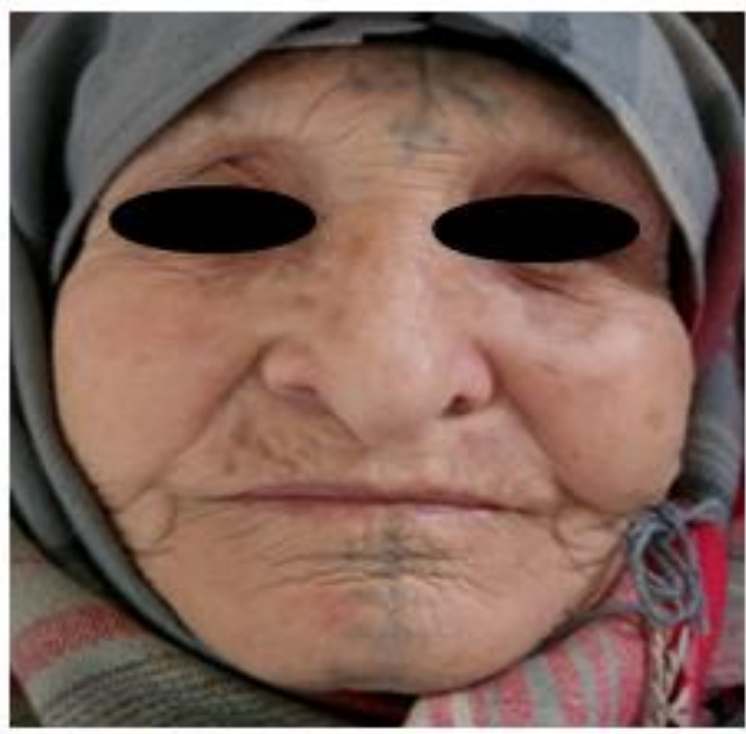

Fig-5: Results at 2months (Front view)

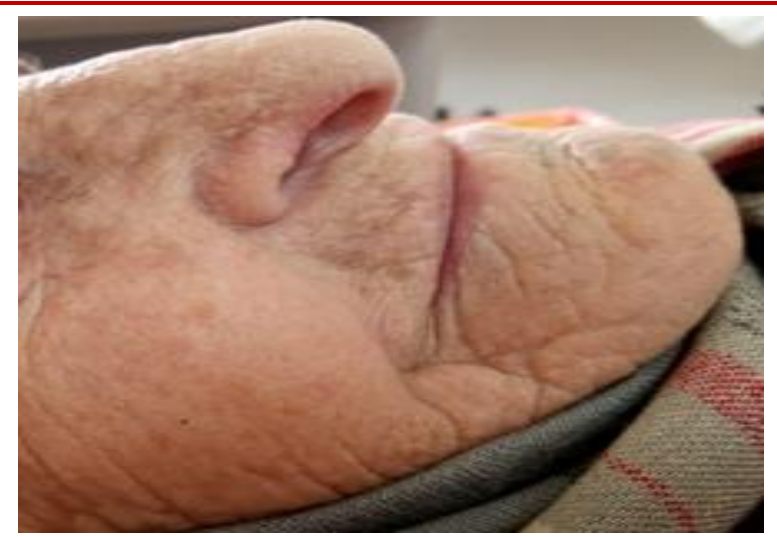

Fig-6: Results at 2months (Profile view)

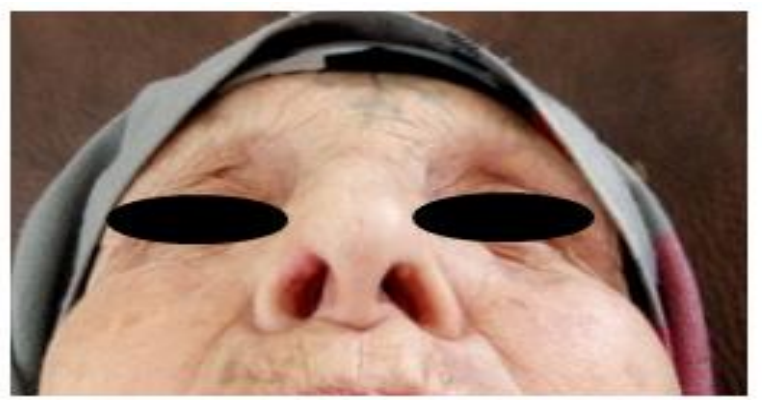

Fig-7: Results at 2months (Basal view)

\section{DISCUSSION}

Chondroidsyringoma is a rare, benign adnexal skin tumor with an epithelial and mesenchymal component. First described in 1859 by Billroth, it was initially called "mixed tumor or myxoid of the skin", by analogy with mixed tumors of the salivary glands $[1,2]$. In 1961, Hirsch and Helwig introduced the name "chondroidsyringoma" in order to differentiate common mixed tumors of the salivary or lacrimal glands from those, much rarer, of the skin, originating in the sweat glands [2, 3]. In the same year, Headington differentiated two types: apocrine and eccrine, characterized respectively by a double cuboid cell base, and small tubular lumens with a single cell base [4].

The median age is 50 years (range: 23-77 years) with a predominance of men. The sex ratio varies between $1.3 / 1$ and $5 / 1[5,6]$.

The cervico-facial sphere with the lip, nose and eyebrow as elective seats; remain the preferred location for chondroidsyringoma. It should be noted that two cases of intraorbital localization with exophthalmos and reduced visual acuity have been reported in the literature [7]. Members are alsoaffected.

Classically, chondroidsyringoma manifests itself in the form of a slowly growing, painless subdermal nodular mass that is mobile in relation to the deep plane, the measurements of which vary from 0.5 to $3 \mathrm{~cm}$ [5]. Apart from cases of malignant transformations, sporadic cases of benign and giant chondroidsyringomahave been reported in the literature [8]. It can also manifest as a pearly-looking, 
H. Kabbaj et al; Saudi J Oral Dent Res, Apr, 2021; 6(4): 166-168

telangiectatic nodule with the presence of ulceration, suggesting basal cell carcinoma, which is one of the differential diagnoses [9]. The differential diagnosis will be made mainly with an epidermal inclusion cyst, an amelanic nevus, a sebaceous cyst, a dermoid cyst, a schwannoma, a neurofibroma, a pilomatricoma and a basal cell carcinoma [5] as well as with other lesions. benign orbital including pleomorphic adenoma, lipomas, neurofibromas, meningiomas, lymphangiomas and others in its intra-orbital location [7].

The confirmatory diagnosis is made by histology which shows a mixed tumor; with epithelial and mesenchymal component. The mesenchymal component can be myxoid, chondroid, adipose or fibrous and contains clusters of epithelial cells without glandular structure or isolated cells. The epithelial contingent is made up of glands whose histological appearance makes it possible to individualize two types: the apocrine type (tubular or cystic glands, focally branched, lined with a double layer of cuboid or flattened cells) and eccrine (narrower lumens and glands bordered by a single cell layer). From an immunohistochemical point of view, the cells of the inner layer of the glands are marked by the anti-keratin, anti-epithelial membrane antigen and anticarcinoembryonic antigen antibodies, demonstrating their epithelial nature. Cells in the outer layers do not express these antigens, but they express the S100 protein and vimentin suggesting a common mesenchymal origin $[4,5,10]$.

The standard treatment is based on complete surgical excision with a $3 \mathrm{~mm}$ margin. Although rare, the risk of malignant transformation is possible, especially in cases of incomplete excision of a benign form; hence the interest of annual monitoring. De novo malignant forms have been reported in the literature. Their treatment is surgical based on excision with a safety margin of $1 \mathrm{~cm}[11,12]$.

\section{CONCLUSION}

Chondroid syringoma is an adnexal tumor. It is rarely mentioned because it is little known; however, its histological diagnosis remains easy, based on the demonstration of a double epithelial and mesenchymal component. Despite well-conducted surgical treatment, continuous annual monitoring is required due to the possibility, although rare, of malignant transformation.

Conflicts of Interest: The authors declare no conflict of interest.

Authors ' Contribution: All the authors contributed to the conduct of this work.

\section{REFERENCES}

1. Castillo Molina, D., Dubeibe Abril, P., Benjumea Nieto, P., Blanco Gomez, J., Martinez Zuniga, D.,
Castillo, D. E., \& Morales Naranjo, S. (2019, October). Mixed cutaneous tumor: Chondroid syringoma a case report. In Journal of the American Academy of Dermatology (Vol. 81, No. 4, pp. AB240-AB240). 360 PARK AVENUE SOUTH, NEW YORK, NY 10010-1710 USA: MOSBY-ELSEVIER.

2. Varsori, M., Dettwiler, S., \& Chaloupka, K. (2007). Syringome chondroïde de la paupière: à propos d'un cas. Journal Francais d'Ophtalmologie, 30(1), 75-e1.

3. Hirsch, P., \& Helwig, E. B. (1961). Chondroid syringoma: Mixed tumor of skin, salivary gland type. Archives of dermatology, 84(5), 835-847.

4. Aoun, A., Dufrenot-Petitjean-Roget, L., Amazan, E., Derancourt, C., Alexandre, M., Quist, D., ... \& Molinié, V. (2015, August). Syringome chondroïde cutané. In Annales de Pathologie (Vol. 35, No. 4, pp. 275-280). Elsevier Masson.

5. Abil, S., Bouhllab, J., Zarkik, S., Lamchahab, F. Z., \& Saidi, A. (2012). Syringome chondroïde de la face. In Annales de dermatologie et de vénéréologie (Vol. 139, No. 10, pp. 681-683).

6. Mlika, M., Goutallier-Ben Fadhel, C., Lahmar, A., Rekik, W., \& Lafif, F. H. (2009). Une tumeur palpébrale inhabituelle. Annales de pathologie (Print), 29(3), 249-251.

7. Elkhoyaali, A., Chatoui, S., Omari, A., Khmamouche, M., Moumen, H., Belmalih, M., ... \& Oubaaz, A. (2015). Benign chondroid syringoma of the orbit: A case report. Journal francais d'ophtalmologie, 38(10), e249-e251.

8. Kakitsubata, Y., Theodorou, S. J., Theodorou, D. J., Nakahara, M., Yuki, Y., \& Yokouchi, T. (2009). Syringome chondroïde géant se présentant comme un masse sous-cutanée dans le bras: aspects en IRM et corrélation anatomopathologique. Revue du rhumatisme, 76(12), 1363-1366.

9. González, L. L., Carreras, P. A., Villafranca, B. R., \& Navarro-Triviño, F. J. (2020). Chondroid Syringoma Mimicking Basal Cell Carcinoma. Actas dermo-sifiliograficas, 111(4), 341-343.

10. Girgis, S., Gillan, G., \& Piper, K. (2015). Chondroid syringoma of the upper lip: a case report. British Journal of Oral and Maxillofacial Surgery, 53(10), e77.

11. Chauvel-Picard, J., Pierrefeu, A., Harou, O., Breton, P., \& Sigaux, N. (2018). Unusual cystic lesion of the eyebrow: A case report of malignant chondroid syringoma. Journal of stomatology, oral and maxillofacial surgery, 119(3), 232-235.

12. Ka, S., Gnangnon, F., Diouf, D., Dieng, M. M., Thiam, J., Gaye, M., \& Dem, A. (2016). Malignant chondroid syringoma in a West African cancer institute: a case report. International journal of surgery case reports, 25, 137-138. 